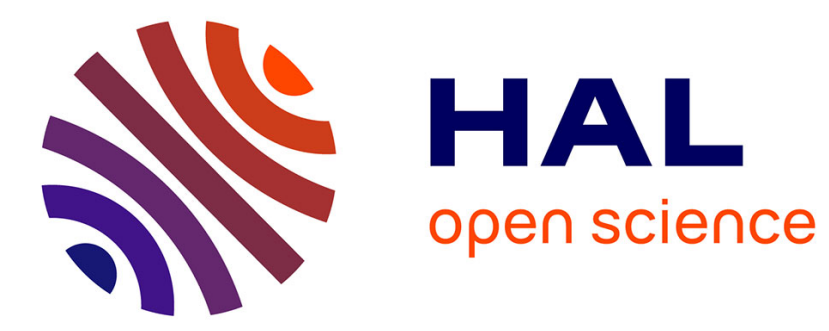

\title{
Sediment trapping by a tree belt: processes and consequences for sediment delivery
}

Sophie Leguédois, Tim Ellis, Peter Hairsine, David Tongway

\section{To cite this version:}

Sophie Leguédois, Tim Ellis, Peter Hairsine, David Tongway. Sediment trapping by a tree belt: processes and consequences for sediment delivery. Hydrological Processes, 2008, 22 (17), pp.35233534. 10.1002/hyp.6957 . hal-02659353

\section{HAL Id: hal-02659353 \\ https://hal.inrae.fr/hal-02659353}

Submitted on 30 May 2020

HAL is a multi-disciplinary open access archive for the deposit and dissemination of scientific research documents, whether they are published or not. The documents may come from teaching and research institutions in France or abroad, or from public or private research centers.
L'archive ouverte pluridisciplinaire HAL, est destinée au dépôt et à la diffusion de documents scientifiques de niveau recherche, publiés ou non, émanant des établissements d'enseignement et de recherche français ou étrangers, des laboratoires publics ou privés. 


\title{
Sediment trapping by a tree belt: processes and consequences for sediment delivery
}

\author{
Sophie Leguédois* $\quad$ Tim W. Ellis ${ }^{\dagger} \quad$ Peter B. Hairsine ${ }^{\ddagger}$ \\ David J. TongwaY ${ }^{\S}$
}

October 21, 2007

${ }^{*}$ Corresponding author. INRA, UR272 - Science du sol, BP 20619, F-45166 Olivet, France. Presently at Laboratoire d'écologie fonctionnelle (EcoLab) - UMR 5245 CNRS / Université Paul Sabatier / INP-ENSAT, BP 32607, F-31326 Castanet-Tolosan, France. Phone: +33 (0)5 621939 00. Fax: +33 (0)5 621939 01. Email: sophie.leguedois@ensat.fr

${ }^{\dagger}$ CSIRO Land and Water, GPO Box 1666, Canberra ACT 2601, Australia. Phone: +61 (0)2 62465743. Email: tim.ellis@csiro.au

¥CSIRO Land and Water, GPO Box 1666, Canberra ACT 2601, Australia. Phone: +61 (0)2 62465924. Email: peter.hairsine@csiro.au

${ }^{\S}$ CSIRO Sustainable Ecosystems, GPO Box 284, Canberra City ACT 2601, Australia. Phone: +61 (0)419 861 615. Email: david.tongway@csiro.au 
2 Restoring belts of perennial vegetation in landscapes is widely recognised as a measure 3 to improving landscape function. While there have been many studies of the transport 4 of pollutants through grass filter strips, few have addressed sediment related processes 5 through restored tree belts. In order to identify these processes and to quantify their rel6 ative contribution to sediment trapping, a series of rainfall simulations was conducted on 7 a $600-\mathrm{m}^{2}$ hillslope comprising a pasture upslope of a 15-year-old tree belt. Although the 8 simulated events were extreme (average recurrence intervals $\sim 10$ and $50 \mathrm{y}$ ), the trapping 9 efficiency of the tree belt was very high: at least $94 \%$ of the total mass of sediments was captured. All the size fractions were trapped with a minimum Sediment Trapping Ratio 1 (STR) of $91 \%$ for the medium-sized fragments. Fractions $<1.3 \mu \mathrm{m}$ and $>182 \mu \mathrm{m}$ were totally captured $(\mathrm{STR}=100 \%)$. Through the joint analysis of sediment budgets and soil surface conditions, we identified different trapping processes. The main trapping process is the sedimentation (at least $62 \%$ of trapped sediment mass) with deposits in the back-

\section{${ }_{23}$ Abbreviations}

ASD Aggregate Size Distribution

COF Coarse Organic Fragments 
1 MSF Mineral Soil Fragments

2 MWD Mean Weight Diameter

3 P Pasture, referring to the pasture plot

4 P+TB Pasture + Tree Belt, referring to the pasture + tree belt plot

5 RMSE Root Mean Square Error

6 TB Tree Belt, referring to the tree belt plot

7 VFS Vegetative Filter Strip

\section{\& Introduction}

9 Managed rows of trees or shrubs are common features in agricultural landscapes through-

10 out the world (Baudry et al., 2000). They have been promoted as a measure for a wide

11 range of benefits and functions related to water management, soil conservation, biodiver-

12 sity or farming production (e.g. see Kang et al., 1990; Baudry et al., 2000; Stirzaker et al.,

13 2002; Droppelmann and Berliner, 2003). When located between agricultural land and

14 waterbodies in the form of tree belts, they can be used as a Vegetative Filter Strip (VFS)

15 to trap agricultural diffuse pollution transported by overland flow and, consequently to

16 improve the quality of surface water.

17 Sediments, which are generated by water erosion on agricultural lands, are one form of 18 diffuse agricultural pollution that impairs water quality by increasing the turbidity and the 19 delivery of particle-bound chemicals. VFSs have been shown to present a high trapping capacity and to be an effective tool to control sediments from agricultural lands (e.g. 21 see the reviews by Dosskey, 2001; Helmers et al., 2005). However most of the studies 22 concern grass strips (Dosskey, 2001) or tree and shrub strips implemented downslope of a grass strip (Daniels and Gilliam, 1996; Schmitt et al., 1999; Sheridan et al., 1999; Lee 
1 et al., 2000) and few studies (Cooper et al., 1987; Hairsine, 1996; Loch et al., 1999) have 2 focussed on sediment trapping by tree belts alone.

A range of different processes act within VFS to trap sediments (Dosskey, 2001). Sedimentation is the best known trapping process. It occurs when the flow velocity is retarded by the VFS and, consequently, the sediment transport capacity decreases. Most of the time, sedimentation happens in the ponding areas, called backwater, that formed upstream of the VFS (Dillaha et al., 1988; Dabney et al., 1995; Meyer et al., 1995; Ghadiri et al., 2001). Deposits can also be found within the VFS itself (Dillaha et al., 1988). Sedimentation can be enhanced by the loss in runoff discharge due to the high infiltration capacity in the strip (Hayes et al., 1984; Lee et al., 1989). The removal of particles in surface runoff, with the infiltration of water, has also been evoked as another possible trapping process (Lee et al., 2000; Dosskey, 2001).

In most of the work on sediment trapping in VFSs, the buffer zone is considered as a black box and the specific impact of the various trapping processes are not examined (e.g. see Hayes et al., 1984; van Dijk et al., 1996; Muñoz-Carpena et al., 1999; Lee et al., 2000; Le Bissonnais et al., 2004). Trapping processes, especially backwater sedimentation, have been analysed in detail in laboratory studies with disturbed soils (Dabney et al., 1995; Meyer et al., 1995) or flume beds (Jin and Römkens, 2001; Ghadiri et al., 2001; Jin et al., 2002) and, consequently, are not representative of field conditions. If knowledge on sediment trapping processes is scarce for VFS in general, it is lacking for tree belts in particular.

Movement of material on the soil surface leaves characteristic visual features, like deposits or sealing, which can be used to track the processes (Auzet et al., 1993; Tongway and Hindley, 2004; van Dijk et al., 2005). The monitoring of the soil surface conditions can be used as a rapid tool to obtain information on the trapping processes acting within a VFS. Trapping can also change the size distribution of the flux of sediments. For example, the coarsest size fractions are selectively deposited over an area of sedimentation (Beuselinck et al., 1999b). So, information on the processes acting within a VFS can be 
1 obtained by analysing the size distribution of sediments entering and leaving the buffer 2 zone.

3 The objectives of the work presented in this paper are (i) to identify the trapping pro4 cesses within a tree belt and (ii) to assess their relative contribution to the total sediment 5 trapping, by analysing changes in soil surface conditions, as well as input and output sus6 pended sediment size distribution. A field experiment was performed in order to have 7 realistic soil conditions. The hydrological aspect of this work is reported by Ellis et al. 8 (2006).

\section{, Materials and methods}

\section{Study site}

11 The experimental site was located on a grazing property near Boroowa (-34 $22^{\prime} \mathrm{S} 148^{\circ} 42^{\prime}-$ E), New South Wales, Australia. The studied tree belt was aligned perpendicular to the slope $\left(6^{\circ}\right)$ in the lower part of a hillslope covered with sheep pasture. The trees were directly seeded in 1990 mainly with Acacia spp. and Calistemon spp. so that the trees have been established for $15 \mathrm{y}$ at the time of the experiment. The tree belt was originally setup by the landholder for stock shelter and biodiversity habitat. Stock were excluded from the chromic luvisol (Driessen et al., 2001) with a silt loam surface horizon.

\section{${ }_{19}$ Experimental layout}

20 The experiment was conducted on a $15 \times 40 \mathrm{~m}^{2}$ area which comprised $15 \times 28 \mathrm{~m}^{2}$ of 21 grazed pasture draining into $15 \times 12 \mathrm{~m}^{2}$ of tree belt (Fig. 1). The experimental area was divided into three plots (Fig. 1) in order to assess the behaviour of respectively: (i) the whole system (plot $\mathrm{P}+\mathrm{TB}$ ), i.e. pasture draining into the tree belt; (ii) the pasture itself

24 (plot P); (iii) and the tree belt itself (plot TB). The plots edges were formed by strips of 
1 sheet steel, embedded in the soil $\sim 40 \mathrm{~mm}$ and sealed at soil level with liquid petroleum 2 jelly. At each plot outlet the runoff water and sediment were collected in a gently inclined $3\left(2^{\circ}\right)$ steel trough and then directed into a portable 'RBC' flume (Bos et al., 1991) . In order to have two similar pasture-tree belt sequences, we located the experimental area on a part of the study site with uniform slope, soil conditions, as well as pasture and 6 tree covers. Ellis et al. (2006) demonstrated, with two analytical checks, that any likely error in the surface water budget due to spatial variation between the sequences was likely 8 to be smaller than the measurement errors. This choice of experimental configuration

9 10 11 12

was necessary to allow sequences comparison. However it artificially favoured sheet flow whereas flow concentration, which is likely to occur on farm, was shown to impair sediment trapping (Dillaha et al., 1989; Dosskey, 2002).

\section{Rainfall simulation}

Rainfall was applied on the whole $600 \mathrm{~m}^{2}$ experimental plot using a large portable rainfall simulator. Details on the setup of this rainfall simulator are given in Wilson (1999).

Twenty risers which support the nozzles were arranged on the plot in a triangular pattern, with $6 \mathrm{~m}$ between each riser (Fig. 1). The risers were $3 \mathrm{~m}$ high in the pasture and $7 \mathrm{~m}$ high, above the tree tops, in the tree belt. The setting of the sprinklers above the tree tops ensured to reproduce rainfall interception by the canopy. Even if the rainfalls were quite variable over the experimental area (see standard deviation values in Table 1) the rainfall homogeneity between the plots was good (Table 1) as weather conditions were windless at the time of the experiments.

Three simulated rainfall events were successively applied over the experimental area (Table 1): a pre-wetting event at medium intensity to ensure an initial wet soil surface, and two longer run events at medium and high intensity. Time constraints required that rainfall events were applied sequentially within $\sim 30$ min of each other. These rainfall events are quite exceptional for the region of Boorowa with important Average Recurrence Intervals (ARI, see Table 1), i.e. the average, or expected, value of the periods between exceedances 
1 of a given rainfall total accumulated over a given duration. These intense rainfall events 2 enable us to test the tree belt trapping capacity for extreme conditions, i.e. concentrated 3 flow or exceptional rainstorm, when it is expected that much of the long term flux of 4 sediment occurs

\section{Measurements and sampling}

6 Flow depths were measured manually at 3 min intervals using a ruler in portable 'RBC' flumes (Bos et al., 1991). Depths were converted to discharge rates using the relationship provided by Bos et al. (1991).

At each sampling site, two overland flow samples were taken every 3 min at the bottom of the trough, just below the flume, during the runoff event, i.e. during the rainfall as well as during the hydrograph recession period. The first set of samples was processed to water and sediment mass, then oven-dried at $105^{\circ} \mathrm{C}$ and finally weighed again to obtain the dry sediment mass.

The second set was used to determine aggregate size distribution (ASD) of the sediments by combining sieving and laser diffraction analysis data. The ASD is the size 
1 for the samples collected at the outlet of plot TB during event \# 1. All the undersize sam-

2 ples or sub-samples with a sufficiently high sediment concentration were analysed by a 3 laser diffraction sizer (Malvern Mastersizer 2000) which gave the volume distribution of 468 fractions (i.e. the maximum number of fractions available for this sizer) between 0.02 5 to $2000 \mu \mathrm{m}$. The limits of the fractions were set in order to logarithmically increase the 6 size range with the diameter. As the laser diffraction sizer measures volume distribution, 7 the ASDs were expressed in volume percentage. In case of sub-sampling, the measured 8 size distributions $S_{i j}$ of all the $n$ sub-samples $j$ for a given sample $i$ were averaged by 9 arithmetic mean:

$$
{ }_{10} \quad S_{i}=\frac{\sum_{j=1}^{n} S_{i j}}{n} \text {. }
$$

11 The undersize and oversize fractions were then oven-dried $\left(105^{\circ} \mathrm{C}\right)$ and weighed in order 12 to determine their relative proportion. To assess the impact of two diameter sieve sizes on size measurement, the ASDs of samples collected from the same event (event \# 2) and plot 14 (plot P+TB) were compared. As shown on Figure 2, the differences between the ASDs

$$
M W D=\frac{\sum^{i} p(i) \times \phi(i)}{\sum^{i} p(i)},
$$

24 where $p(i)$ and $\phi(i)$, are the volume percentage and the arithmetic mean size of a given 25 size fraction $i$ respectively. 


$$
\rho_{23}=\frac{\sum^{j}\left(m_{w}(j) \times \frac{m_{w}(j)}{v(j)}\right)}{\sum^{j} m_{w}(j)} .
$$

$\rho_{21}=\frac{\sum^{j}\left(m_{d}(j) \times \frac{m_{d}(j)}{v(j)}\right)}{\sum^{j} m_{d}(j)}$ and

For some samples taken during the steady state runoff phase, the settling velocity distribution was determined with the automated settling column proposed by Loch (2001) from a design of Hairsine and McTainsh (1986). The settling velocity distributions were expressed in mass percentage.

After drying, a subset of the oversize fractions was analysed for bulk density. Depending on their shape, the constituents were divided into different categories. For each shape fraction $j$, the different necessary to determine the dry and the wet bulk densities were measured. The dry samples were weighed for dry mass, $m_{d}(j)$ (in g). The volume of each shape fraction, $v(j)$ (in $\mathrm{cm}^{3}$ ), was determined on the dry samples by combining image acquisition with a flat bed scanner and image analysis with the software WinRHIZO (C) (Regent Instrument INC, 2005). For the fractions with round-shaped particles (mainly sticks and some spherical fruits), the software gave directly a volume estimate by assuming all the particles were cylindrical. For the fractions with flat-shaped particles, only the projected surface area was determined by image analysis and the average thickness was measured using vernier callipers. For wet mass $\left(m_{w}(j)\right.$, in $\left.g\right)$ measurement, the shape fractions were wetted before weighing by soaking the samples for $1 \mathrm{~h}$ and then air-drying for $1.5 \mathrm{~h}$ until no free water was present. None of the shape fractions showed a measurable swelling, so the volume of the wet samples was assumed to be the same as the volume of the dry samples. The dry bulk density, $\rho_{d}\left(\mathrm{~g} \cdot \mathrm{cm}^{-3}\right)$, and the wet bulk density, $\rho_{w}\left(\mathrm{~g} \cdot \mathrm{cm}^{-3}\right)$, were computed for the whole size fraction as mean weight densities: 


\section{Data computation}

8 The total mass of soil leaving a given experimental plot $j$ and for a given runoff event, $M_{j}$

$9(\mathrm{~kg})$, was computed by piecewise integration of the equation:

$$
M_{j}=\int_{t_{i}}^{t_{e}}\left(q_{j}(t) \times c_{j}(t)\right) d t,
$$
event, the soil surface condition was assessed along 4 transects of the experimental area following the method of Tongway and Hindley (2004). This careful visual assessment of the soil surface evolution gave useful evidences to aid in the interpretation of measured sediment movement.

where $t_{i}$ the time to incipient runoff, $t_{e}$ the time that runoff ends, $q_{j}(t)$ the water discharge rate and $c_{j}(t)$ the sediment concentration. $q_{j}(t)$ and $c_{j}(t)$ were determined by linear interpolation from discrete measurements of water discharge rates and sediment concentration respectively, at the outlet of plot $j$.

The mass of sediments produced by the pasture and delivered to the upper limit of the tree belt, $Q_{\text {input }}(\mathrm{kg})$, can either be trapped by or pass through the tree belt. At the outlet, the total mass of sediments, $Q_{\text {output }}(\mathrm{kg})$, contains only sediments which passed through the tree belt as well as sediments that were produced within the tree belt. As a consequence, the total net mass of sediments trapped within the tree belt equals:

$$
Q_{\text {trap }}=Q_{\text {input }}-Q_{\text {output }}+Q_{\mathrm{TB}} \text {, }
$$

where $Q_{\mathrm{TB}}(\mathrm{kg})$ is the mass of sediments produced within the tree belt. $Q_{\text {input }}, Q_{\text {output }}$ and $Q_{\mathrm{TB}}$ were assessed by the measurements made at the outlets of plot $\mathrm{P}$, plot $\mathrm{P}+\mathrm{TB}$, and plot $\mathrm{TB}$, respectively.

The sediment budget for the tree belt compartment was estimated by a Sediment Trap-

Spatial and temporal changes in overland flow and associated changes in soil surface conditions were recorded during all the rainfall events. Before and after each rainfall 
1 ping Ratio, defined as STR:

2 $\quad \mathrm{STR}=\frac{Q_{\text {trap }}}{Q_{\text {input }}}=\frac{M_{\mathrm{P}}-M_{\mathrm{P}+\mathrm{TB}}+M_{\mathrm{TB}}}{M_{\mathrm{P}}}$,

${ }_{3}$ where $M_{\mathrm{P}}, M_{\mathrm{P}+\mathrm{TB}}$ and $M_{\mathrm{TB}}$, are the total masses of sediment collected at the outlets of 4 plots $\mathrm{P}, \mathrm{P}+\mathrm{TB}$, and TB, respectively. The STR is related to the more classically used Sed5 iment Delivery Ratio SDR (e.g. Beuselinck et al., 1999a; Muñoz-Carpena and Parsons, 6 2004) by the following equation:

$7 \quad \mathrm{SDR}=1-\mathrm{STR}$.

\section{${ }_{8}$ Results}

\section{Runoff characteristics and capture}

Ellis et al. (2006) provide a detailed analysis of the surface hydrology. Only a brief 1 summary is presented here. The runoff generation within the pasture was mainly governed 12 by a bare and crusted zone in the 3.5-m area upslope of the tree belt (see Figure 1). The absence of vegetation in this zone is probably due to tree-pasture competition for soil water and animal activities such as grazing, trampling and camping in the shade. The specific discharges measured at the outlet of plot $\mathrm{P}$ during the steady state period reached $0.134 \pm 0.005$ and $0.298 \pm 0.009 \mathrm{l} \cdot \mathrm{s}^{-1} \cdot \mathrm{m}^{-1}$ (average \pm standard error) for event \# 1 and 


\section{Evolution of the soil surface conditions in the tree belt}

2 Within the tree belt the initial soil surface conditions consisted of a dense tree litter on 3 approximately $83 \%$ of the experimental area, while a sparse tree litter existed on the 4 remaining area. The litter was made of narrow, interlocking foliage as well as fine twigs.

5 When the overland flow, produced by the pasture area in plot $\mathrm{P}+\mathrm{TB}$, reached the tree belt, 6 it removed the litter fragments and rearranged them in small litter dams up to $25 \mathrm{~mm}$ high 7 and approximately $100 \mathrm{~mm}$ apart (Figure 3). These litter dams started to form during the 8 pre-wetting event. This surface condition remained present throughout the experiment. 9 During the rainfall events, the litter dams slowed the flow and led to the formation of small 10 ponds just upstream of each of them. Once the rainfall stopped, the ponds emptied. The 11 deposition of sediment in these ponds created micro-terraces (Figure 3). The formation

of the litter dams took place in the whole tree belt but micro-terraces development mainly occurred in the first $1.5 \mathrm{~m}$ of the belt area. Both processes were active during all rainfall events. The micro-terraces were no more than 1-mm-thick, with a maximum thickness located in the concentrated flow paths that appeared during event \# 1. The same processes, litter dam building and micro-terrace formation, were also apparent in plot TB. However these processes were far less intense in this plot since no overland flow entered from the pasture.

Another soil surface feature which changed during the rainfall events was the presence of macropore openings at the soil surface. Before rainfall simulations, the tree belt soil contained 5-to-10-mm diameter macropores which were open at the surface. They were mostly found beneath the tree litter within the first 1 to $2 \mathrm{~m}$ of the tree belt. Some of them were tagged at the beginning of the rainfall. After event \# 1 , they were filled with sediment.

During the two rainfall events, on plot $\mathrm{P}+\mathrm{TB}$, water ponded just upslope from the tree belt, right at the interface of the pasture and the tree belt areas. The formation of the backwater was accentuated, during the pre-wetting event, by the development of a litter barrier due to the washing of plant debris that was initially located in the bare soil zone. 
1 The ponded water led to the deposition of a triangular-shaped wedge of sediment with the 2 maximum depth $(1.2 \mathrm{~cm})$ just upstream from the litter barrier. This deposit, situated along

3 the whole length of the pasture-tree belt interface, was about $60 \mathrm{~cm}$ wide. Considering 4 a bulk density value of $1.4 \mathrm{~g} \cdot \mathrm{cm}^{-3}$, as measured by Takken et al. (1999), we computed 5 that $\sim 38 \mathrm{~kg}$ of sediments accumulated at this location during the pre-wetting phase and 6 the two rainfall events. This corresponds to an average mass per unit width of tree belt of $5.1 \mathrm{~kg} \cdot \mathrm{m}^{-1}$. In plot $\mathrm{P}$, no ponded area formed and no backwater deposition was observed 8 upstream of the collection trough.

\section{. Sediment size distributions}

10 MWD values were computed from the ASDs determined by laser diffraction method.

11 These values allowed determination of the temporal evolution of the size distribution dur12 ing rainfall events. The results (Figure 4), show that the MWD values are quite steady for 13 a given sample set. The only noticeable change in the MWD is the sharp increase after 14 rainfall has ceased for the two series collected at the outlet of plot P. So, the sediment

size distribution leaving the different hillslope plots seems to stay constant during rainfall simulation. Once the rainfall had ceased and the runoff rate decreased, the sediments that had left the pasture plot tended to get coarser.

The average sediment size distributions that left the three hillslope plots during the two events are shown in Figure 5. Only samples collected during a rainfall event were taken into account to compute these distributions, and the samples collected during the recession period were excluded. No particles were detected in the coarsest size fraction ranging between 1905 to $2108 \mu \mathrm{m}$.

For a given plot, the ASDs were very similar across rainfall events. The data show only a small enrichment in the medium-size fraction for event \# 2 as compared to event \# 1. This enrichment occurred in the fractions between 5 and $150 \mu \mathrm{m}$ for the P+TB plot, and the fractions between 30 and $150 \mu \mathrm{m}$ for the $\mathrm{P}$ plot.

The sediments that moved from plot $\mathrm{P}$ had the finest ASD. The measured size range 
1 is from 0.5 to $1900 \mu \mathrm{m}$. Sediments collected at the outlet of plot TB (data available only

2 for event \# 2) were the coarsest, with a measured size range from 3 to $1900 \mu \mathrm{m}$ and $92 \%$ 3 of their volume made up of coarse-size fraction between 479 and $1660 \mu \mathrm{m}$. For plot

${ }_{4} \mathrm{P}+\mathrm{TB}$, the ASDs have a shape quite similar to the ASD measured from plot TB with a 5 higher proportion of medium sediment sizes (from around 8 to $150 \mu \mathrm{m}$ ). The sediments

6 from plots TB and P+TB mostly consisted of the 479 to $1660 \mu \mathrm{m}$ size fraction which was 7 nearly $90 \%$ and $84 \%$ of the volume for event \# 1 and event \# 2, respectively. The high 8 contribution of the coarse-size fraction is the most distinctive characteristic of the ASDs 9 measured on these plots.

\section{Settling velocity distributions}

11 The three measurements of settling velocity distribution are given in Figure 6. The settling 12 velocity distributions of sediment particles measured at the outlet of plot $\mathrm{P}$ are quite sim13 ilar for the two rainfall events. The graph also shows that the soil fragments from plot $\mathrm{P}$ 14 settle faster than the soil fragments that leave plot P+TB. In fact, for the settling velocity distribution measured for the sediments from plot $\mathrm{P}+\mathrm{TB}$, more than $40 \%$ of the particles were slower than $4.2 \cdot 10^{-4} \mathrm{~m} \cdot \mathrm{s}^{-1}$, whereas this velocity fraction represents only around $175 \%$ of the sediments leaving plot P. This result suggests that the sediments entering the tree belt are significantly denser than those leaving the tree belt.

\section{Nature of the sediments}

Complementary information on the nature of the fractions were obtained by visual observation of the collected sediments. The runoff at the outlet of plot $\mathrm{P}$ was a turbid, light brown suspension without visible coarse particles. The colour of the suspension suggests the sediments were predominately Mineral Soil Fragments (MSF). For the prewetting rainfall event, the sediments leaving plot $\mathrm{P}$ contained some plant debris which was washed from the bare soil zone. At the outlet of plot TB, the runoff was a relatively clear suspension containing organic debris. Thus, the sediments leaving the tree belt con- 
1 sisted of Coarse Organic Fragments (COF). A close look at the COF shows mostly leaves

2 (whole or fragmented) of Calistemon spp. and Acacia spp., small sticks, and grass frag3 ments. The runoff from plot $\mathrm{P}+\mathrm{TB}$ was a light turbid suspension of organic debris with 4 the same composition as that for plot TB. Thus, the sediments from plot P+TB were a mix 5 of MSF and COF. The oversize runoff samples from plots $\mathrm{TB}$ and $\mathrm{P}+\mathrm{TB}$, contained only

6 COF. So, the total net masses of the oversize sediment fractions from these plots equal to the masses of oversize COF.

The wet and dry bulk densities of the oversize COF are given in Table 3. These bulk densities of less than $1 \mathrm{~g} \cdot \mathrm{cm}^{-3}$, are low compared to the soil aggregate bulk density (e.g. see Chepil, 1950; Park and Smucker, 2005) and water density. So, the COF is a light solid fraction that floats in water.

These observations are consistent with the ASD (Figure 5) as well as the settling velocity distribution (Figure 6) data. The sediments from plot TB have a coarse size distribution without fractions finer than $10 \mu \mathrm{m}$. The sediments from plot $\mathrm{P}$ have a finer size distribution, with a small proportion of coarse size fractions, but a high settling velocity. And the sediments from plot $\mathrm{P}+\mathrm{TB}$ have a coarse size distribution, quite similar to the ASD of plot TB with a higher proportion of fine fractions, but show a smaller settling velocity.

\section{Total sediment budget}

The total mass of sediment at the outlet of the different plots, as well as the sediment budget for the two events, are given in Table 4. The pasture area shows the highest erosion rates with 0.95 and $1.98 \mathrm{t} \cdot \mathrm{ha}^{-1}$ for event \# 1 and event \# 2, respectively. The erosion rate is far lower for the tree belt zone with values at 0.002 and $0.039 \mathrm{t} \cdot \mathrm{ha}^{-1}$ for event \# 1 and event \# 2, respectively. The whole system, pasture + tree belt, has an intermediate erosion rate with 0.031 and $0.089 \mathrm{t} \cdot \mathrm{ha}^{-1}$ for event \# 1 and event \# 2, respectively. For ungullied grazing landscapes in an adjacent catchment, Armstrong and Mackenzie (2002) found average specific sediment yield of the same order $\left(0.07 \mathrm{t} \cdot \mathrm{ha}^{-1} \cdot \mathrm{y}^{-1}\right)$. The high STR 
1 values, largely above 0.90 , show that the tested tree belt was very efficient in trapping 2 the sediment, even for intense rainfall conditions simulated in this experiment. The trap3 ping efficiency was not significantly influenced by the rainfall intensity: the STR value

4 decreased only very slightly between event \# 1 and event \# 2, while there was a $35 \%$ 5 increase in the rainfall intensity.

\section{${ }_{6}$ Sediment budgets by constituents}

7 The measurements showed that the sediment composition consisted of at least two con8 stituents: Mineral Soil Fragments (MSF) and Coarse Organic Fragments (COF).

9 COF were not observed in the particulate matter entering the tree belt (samples from 10 plot $\mathrm{P}$ ). No COF were delivered to the tree belt and, subsequently, trapped within. COF 11 were present in samples collected at the outlet of the tree belt (samples from plot TB and $\mathrm{P}+\mathrm{TB})$. So there is a net production of $\mathrm{COF}$ within the tree belt and this mass can this directly be determined by the measurements at the outlet of plot $\mathrm{P}+\mathrm{TB}$.

The relative volume proportion of COF and MSF of the undersize sediments from plot $15 \mathrm{P}+\mathrm{TB}$ was determined by comparing the average ASD from plot $\mathrm{TB}$ and that from plot $\mathrm{P}+\mathrm{TB}$. The assumptions underlying this comparison are:

1. the sediments collected at the outlet of plot P+TB are a mix of two constituents, COF and MSF;

2. the sediments collected at the outlet of plot TB contain only COF;

3. the average ASD measured on the samples from plot TB, specifically the high proportion of 479 -to-1660 $\mu \mathrm{m}$ size fraction, is specific to the COF;

4. the COF from plot $\mathrm{P}+\mathrm{TB}$ have the same ASD as the COF sampled from plot TB;

5. the 479-to- $1660 \mu \mathrm{m}$ size fraction of the sediments from plot $\mathrm{P}+\mathrm{TB}$ only consisted of COF. This last assumption is supported by the fact that the coarse fraction that remained after sieving contained only $\mathrm{COF}$. 
1 The comparison was performed with the frequency distribution in order to avoid compli2 cation inherent in comparing cumulative distributions. To evaluate the fit, the Root Mean 3 Square Error (RMSE) was computed for the size fraction characteristic of the COF, i.e. 4 the 479-to-1660 $\mu \mathrm{m}$ size fraction, as well as the two adjacent size fractions, of 417-to${ }_{5} 479 \mu \mathrm{m}$ and 1660-to-1905 $\mu \mathrm{m}$. As the ASD for the sediments yield from plot TB during event \# 1 was not measured, the comparison was only performed for the data of event \# 2. 7 The minimum RMSE was obtained for a volume proportion of COF set at $90.1 \%$. The resulting fit is shown in Figure 7.

Knowing the volume proportion as well as the total mass of the undersize fraction and COF and MSF. The dry bulk density of COF was measured and is given in Table 3. Soil

fragments have a wide range of bulk density (see Chepil, 1950; Park and Smucker, 2005),

from less than $1.4 \mathrm{~g} \cdot \mathrm{cm}^{-3}$ for large aggregates to around $2.6 \mathrm{~g} \cdot \mathrm{cm}^{-3}$ for quartz particles, so we used a range of values for the MSF bulk density. The mass of the undersize fraction was determined by weighing. About 1.5 to $1.8 \mathrm{~kg}$ of undersize COF was produced by the tree belt of plot $\mathrm{P}+\mathrm{TB}$, during event \# 2. By adding the mass of the oversize fraction, which contained only $\mathrm{COF}$, the total mass of COF produced by the tree belt is in the range of 1.8 to $2.1 \mathrm{~kg}$. The total mass of MSF from plot $\mathrm{P}+\mathrm{TB}$ is between 0.6 to $0.9 \mathrm{~kg}$. Considering that the sediments delivered to the tree belt were only made of MSF and that no MSF were produced within the tree belt, the MSF trapping ratio for event \# 2 is between 98 and $99 \%$.

\section{Sediment budgets by size fractions}

The ASD of the MSF from plot $\mathrm{P}+\mathrm{TB}$ for event \# 2 is computed from the difference between the COF size distribution fitted in the previous section (see Figure 7), and the ASD of the total sediments leaving this plot during the same event (see Figure 5). The computed MSF size distribution ranges from $1.1 \mu \mathrm{m}$ to $209 \mu \mathrm{m}$ (see Figure 8).

Knowing the ASDs as well as the total mass of MSF entering and leaving the tree belt, 
1 trapping ratios by size fraction can then be computed from Equation 5. For this computa2 tion, we used an average bulk density of $2.2 \mathrm{~g} \cdot \mathrm{cm}^{-3}$ which was determined from the values measured by Chepil (1950) for silt loam aggregates in the size fractions $<100 \mu \mathrm{m}$ and 4 100-500 $\mu \mathrm{m}$. As shown on Figure 9, the STRs are very high for all the size fractions with 5 a minimum of $91 \%$ and a maximum of $100 \%$. For the finest (from 0.32 to $1.3 \mu \mathrm{m}$ ) and 6 the coarsest (above $182 \mu \mathrm{m}$ ) MSF, the whole mass from plot $\mathrm{P}$ was trapped within the tree 7 belt and no fragments from these size fractions were detected at the outlet of plot P+TB 8 (see Figure 8). For the medium size fractions, the STR is dependent on the fragment size. 9 From 1.3 to $9 \mu \mathrm{m}$ the STR decreases regularly when the fragment size increases and it reaches a minimum between 9 and $15 \mu \mathrm{m}$. From $15 \mu \mathrm{m}$ to $182 \mu \mathrm{m}$, the STR increases with the size.

\section{${ }_{12}$ Discussion}

\section{${ }_{13}$ Total trapping efficiency}

14 Even for intense rainfall events (ARI around 10 and $50 \mathrm{y}$ ), the sediment trapping in the tree belt was very efficient, with a global and minimum STR of 95 and $94 \%$ for events \# 1 and 2, respectively. Even for the most intense rainstorm, event \# 2, the MSF trapping 17 ratio was 98-99 \%. These high values show that the tree belt is able to trap most of the sediments even for extreme conditions such as exceptional rainstorm or concentrated flow. These STRs lie at the upper end of the reported range and are consistent with most of the values given in the literature for VFSs (e.g. see the reviews by Dosskey, 21 2001; Helmers et al., 2005). For example, Helmers et al. (2005) report STR values from 41 to $100 \%$ with a median of $88 \%$. However, most of the published studies concern grass buffers alone or combined with a wooded strip located downslope. The trapping efficiency of forested area alone has been rarely investigated. From the data reported in 25 Table 2 of Lee et al. (2000), STRs for a $9.2 \mathrm{~m}$ long woody (shrubs and tree) buffer can 
1 woody buffer. The sediment loads measured by Sheridan et al. (1999) (see their Table 7) 2 at approximatively $5 \mathrm{~m}$ (position 2) and $30 \mathrm{~m}$ (position 3) from the entrance of a forest 3 riparian buffer show that, at least, 22 to $60 \%$ of the sediment mass was trapped in this 4 wooded area. Comparing inflow and outflow sediment concentrations for 12 short $(0.5$ 5 to 3-m-long) forest plots, Loch et al. (1999) determined transport efficiencies from 16 6 to $98 \%$, which correspond to trapping efficiencies ranging from 2 to $84 \%$. Using the 7 same computation procedure, Hairsine (1996) determined a trapping efficiency greater 8 than $90 \%$ for a 6-m-long near-natural riparian forest. Using ${ }^{137} \mathrm{Cs}$, Cooper et al. (1987) 9 showed that, for a North Carolina watershed, 42 to $45 \%$ of the sediments removed from the cultivated fields over $20 \mathrm{y}$, were deposited within the first $100 \mathrm{~m}$ of a riparian forest.

1 These results suggest that the sediment trapping efficiency should be more variable for 12 forested than for grass filter strips and that very high trapping efficiencies can be expected for forested buffers.

The high variability of sediment trapping for forested areas is probably related to the wide range of observed soil surface conditions: potential development of herbaceous cover; possible presence of tree residues; variation in the extension, the thickness and the nature of surface litter (e.g. see the site descriptions given by Loch et al., 1999). Moreover, the flow characteristics seem to be more heterogeneous in forested than in grass areas (Mackenzie and Hairsine, 1996). As suggested by Darboux et al. (2001), a small local change in roughness at the centimetre scale can have a major impact on runoff and, consequently, on sediment delivery at the plot scale.

For our experiment, the rates of runoff capture by the tree belt were largely lower (32 to $68 \%$ in event \# 1 , and 0 to $28 \%$ in event \# 2) than the sediment trapping ratios. In the experimental data reviewed by Dosskey (2001), the water flow reductions are always lower than the corresponding sediment trapping ratios. The same pattern was observed by Daniels and Gilliam (1996) and Le Bissonnais et al. (2004) among others. All these experimental results point out that sediment trapping processes are only partly linked to the water capture processes. 


\section{Trapping efficiency by size fractions}

2 The STRs, computed by MSF size fraction, indicate that, at least for event \# 2, there

3 was a selective trapping of the coarsest $(>182 \mu \mathrm{m})$ and finest $(<1.3 \mu \mathrm{m})$ fragments.

4 The selective trapping of the coarsest soil fragments, often $>125 \mu \mathrm{m}$, is well known for 5 all kind of VFSs (Dabney et al., 1995; Meyer et al., 1995; Loch et al., 1999; Lee et al., 6 2000; Ghadiri et al., 2001; Jin and Römkens, 2001; Jin et al., 2002; Le Bissonnais et al., 7 2004; Deletic, 2005, 2006). The trapping of the coarse size fractions is due to the greater 8 settling velocities of these fragments which tend to be very quickly deposited when the 9 flow slows (Dabney et al., 1995; Ghadiri et al., 2001; Deletic, 2001). Moreover, larger 10 fragments are also more easily trapped by obstruction in the litter. Consequently, the 11 ASD of the outflow is relatively enriched in fine fractions when compared to the inflow. 12 However reported mass budgets show also that the finest fragments can be trapped within 13 buffers: Jin et al. (2002) obtain STRs from 0 to $55 \%$ for fragments $<63 \mu \mathrm{m}$; the data 14 from the Table 2 of Lee et al. (2000) show STRs for the clay fraction ranging from 27 to $1571 \%$; in the flume experiments of Meyer et al. (1995), $20 \%$ of the sediment fragments 16 from the size fractions under $32 \mu \mathrm{m}$ were trapped. So, even if a large amount of fine soil 17 fragments can be trapped within a VFS, the selective retention of these fractions has not 18 been observed before. Nevertheless, the results presented in Table 2 of Lee et al. (2000) show that the clay fraction is more efficiently trapped by the woody buffer than by the grass buffer. The STRs for clay are $39 \%$ higher for the woody area in comparison with the grass strip whereas, for the sand and the silt fractions, the maximum differences are only 18 and $9 \%$ respectively. Our results, as well as those of Lee et al. (2000), suggest that the trapping of the finest soil fragments could be more efficient in forested filter strips than in the grass strips. 


\section{Trapping processes}

2 The most obvious trapping process noticed during our experiment is sedimentation, i.e.

3 the process of deposition of sediment by water on the soil surface. Sedimentation first oc-

4 curred at the upslope of the tree belt due to backwater ponding. Backwater sedimentation

5 has been widely reported as a key trapping process from various field as well as laboratory

6 experiments (see e.g. Dillaha et al., 1988; Dabney et al., 1995; Meyer et al., 1995; Ghadiri

7 et al., 2001; Lacas et al., 2005) and it has been implemented in VFS models (Hayes et al.,

1984; Muñoz-Carpena et al., 1999; Rose et al., 2002). This process doesn't seem to be

as typical in wooded filter strips: it was observed only for 1 out of the 12 experimental

10 plots tested by Loch et al. (1999). However their experimental conditions were purposely

set to avoid sedimentation in the feeding area of the buffer, and, consequently, were not

conducive to backwater trapping. In our experiment, backwater sedimentation seems to

be the dominant form of sediment trapping. In fact, for the two rainfall events, a total

sediment mass of about $38 \mathrm{~kg}$ settled in the backwater (see page 13), which corresponds

to $66 \%$ and $62 \%$ of the total sediment masses respectively trapped by the tree belt and

leaving the pasture (see Table 4). Sedimentation also occurred within the tree belt itself,

upslope of the small litter dams that formed during the rainfall events. This deposition

led to the formation of micro-terraces. In comparison with the backwater deposit, the

micro-terraces were thinner (no more than $1 \mathrm{~mm}$ ) and extended over a small area (very

patchy and mainly in the first $1.5 \mathrm{~m}$ of the concentrated flow paths). Consequently, the

mass of sediment trapped in these features is not as important as in the backwater.

In the two deposition areas described above, the sedimentation is due to a retardance

of the overland flow caused by the accumulation, on the soil surface of the tree belt area, of

24 litter debris organised as a continuous cover or as barriers. The increased flow retardance

25 within the tree belt is evidenced by the higher values of Manning's hydraulic roughness

26 coefficient for this area compared with the pasture plot (see Table 2). The control of bed

hydraulic roughness on the backwater flow characteristics is clearly showed by Ghadiri

28 et al. (2001) and Rose et al. (2002). Thus, the litter cover was a key surface condition 
1 feature for modifying the water flow and trapping sediments. Such an important role of the 2 tree litter has already been concluded by Daniels and Gilliam (1996) and Hairsine (1996).

3 However, with the action of the overland flow, the litter was drastically reorganised and a 4 significant proportion was exported out of the tree belt as attested by the important mass of COF measured at the tree belt outlet during event \# 2 (1.8 to $2.1 \mathrm{~kg}$ of exported COF). 6 This erosion did not lead to the disappearance of the litter cover and the trapping features were not disrupted even if the simulated rainfall events were extreme. This observation indicates that the trapping capacity of the tree belt should remain on a time scale longer than a rainfall event. However to assess the long-term trapping efficiency, the dynamics of the litter cover should be studied.

The simple settling theory has been successfully used to reproduce the size selectivity over an area of deposition (Dabney et al., 1995; Beuselinck et al., 1999a). To assess the size selectivity of this process for our experimental conditions, we used the backwater sedimentation model, based on the simple settling theory, proposed by Dabney et al. (1995). The settling velocities were computed from the size distributions, using the algorithm of Cheng (1997) with a bulk density of $2.2 \mathrm{~g} \cdot \mathrm{cm}^{-3}$ for wet soil aggregates (Rhoton et al., 1983). The backwater length was assumed to be equal to the length of the deposit, ${ }_{18}$ i.e. $60 \mathrm{~cm}$. The model predicts that the fragments coarser than 50 and $75 \mu \mathrm{m}$, for respectively events \# 1 and \# 2, should be all trapped within the backwater. No fragments finer than $3 \mu \mathrm{m}$ should settle in the backwater. Thus, this process could be responsible for the high trapping ratio for the coarsest MSF (see Figure 9) but cannot explain the trapping of 22 the fine fractions observed during our experiments.

Another trapping process noticed during the experiment is the macropore infilling. The penetration of particles, originated from the soil surface, in the soil profile has already been suggested by Øygarden et al. (1997) and Hardy et al. (1999). The effects of biological macropores on runoff and infiltration have been studied in details by Léonard 27 et al. (2004) but, to our knowledge, the consequences on sediment transport have not been examined yet. In consequence, no information are available about an eventual size 
1 selectivity of this trapping process. However, as the macropores were filled at the end of 2 event \# 1, this process cannot be invoked for the high trapping of fine fractions measured 3 during event \# 2. The clogging of the macropores caused a decline of the trapping capac4 ity of the tree belt. The recovery of this capacity should be linked to the reestablishment 5 of the macropores by biological activity. Thus the time to recovery should depend on the 6 status of the soil macrofauna. On our experimental site, macropores might return within 7 a week, as we noticed ants activity soon after the rain stopped.

Dosskey (2001) suggests that, similarly to dissolved compounds, colloids and clays 9 could be trapped by adsorption on soil surfaces, vegetation and organic debris. Such a process could explain the selective trapping of the fine fractions observed in our experiment. The capture by adsorption of colloids transported in a water flow has been 12 extensively studied within the soil profile (e.g. see DeNovio et al., 2004; Kanti Sen and Khilar, 2006) but, to our knowledge, has not been described at the soil surface. However the importance of adsorption of molecules in solution has been widely shown in VFS and 15 its control parameters have been identified (e.g. see the reviews of Dosskey, 2001; Lacas 16 et al., 2005). During our experiment, the water was forced to flow through the litter cover 17 and barriers present at the surface of the tree area. As the above ground plant debris have 18 a high adsorption capacity (Benoit et al., 1999; Lickfeldt and Branham, 1995), it is likely 19 that the finest soil fragments transported in the overland flow were captured by adsorption on the litter. Such a process could act on the fraction not trapped by the sedimentation ${ }_{21}$ process, i.e. the $<3 \mu \mathrm{m}$ fraction. For event \# 2, this means that, about $960 \mathrm{~g}$ of sediments 22 (i.e. the total mass of soil fragments under $3 \mu \mathrm{m}$ trapped within the tree belt) should be trapped on the surface of the litter debris. This represents only $3 \%$ and $2 \%$ of the total sediment masses respectively trapped by the tree belt and exported from the pasture (see 25 Table 4). 


\section{Conclusion}

2 In this paper, we examined the sediment trapping capacity of a tree belt used as a VFS by 3 analysing data and observations gathered during field rainfall simulations. The computed 4 sediment budgets show that, even for intense rainfall conditions similar to concentrated 5 flow conditions, the studied tree belt was able to trap a high proportion of the delivered 6 sediments: STR was around $95 \%$. These values are slightly higher than the few STRs reported in the literature for forested buffers. The STRs by size fraction computed for the most intense rainfall event lie between 91 and $100 \%$ with a minimum for the medium9 sized fragments. Selective trapping of coarse size fraction is widely reported for VFS and 10 is linked to the sedimentation process. In these circumstances, selective trapping of the soil fragments under $3 \mu \mathrm{m}$ has never been recorded before to our knowledge.

The sediment budgets combined with observations of the soil surface conditions enable us to identify different processes which trap sediment within a tree belt. The main 14 trapping process is the sedimentation in the backwater zone (62\% of the trapped sedi-

ments) and at the micro-terraces formed in the tree belt area. This process is related to the thick litter cover present within the tree belt. The sedimentation trapped the majority of the total sediment mass and selectively the coarsest size fractions. These results are consistent with other literature data. We also clearly identified the trapping effect of the macropores, a process which was only suspected before (Dosskey, 2001; Lacas et al., 2005). Although not confirmed, it is likely that the finest soil fragments transported in overland flow were trapped by adsorption on the numerous litter debris located in the tree belt area. Even if such a process could trap only a very small quantity of sediment, it is crucial to consider it as it concerns the finest fragments which have the highest polluting capacity. This experiment enabled us to identify and to quantify relatively the trapping processes and their effects in term of sediment size distribution for a tree belt. The trapping processes identified here are not specific to tree belts and may be present in other types of VFSs.

The main soil surface features that favoured trapping were the litter cover and the 
1 macropore openings. During the rainfall events, these features were greatly affected by

2 the overland flow. In consequence, the monitoring of the evolution through time of litter

3 cover and biological macropores is necessary to assess the long-term trapping efficiency

4 of the tree belt.

\section{${ }_{5}$ Acknowledgements}

6 The authors are grateful to David Marsh, who encouraged this experiment to be con-

7 ducted on his land; Jim Brophy, who managed the experimental setup and the rainfall

8 simulation; Peter Fogarty, who shared his experience on experimental design and helped

9 for the sampling; Jacky Croke, who gave advices on the experimental design; Martyn El-

10 lis who helped for the experimental setup; all the colleagues from the CSIRO Integrated

11 Catchment Management team who assisted in the sampling and the data recording; and

12 Brian G. Jones, associate professor at Wollongong University, to allow us access to the

13 laser diffraction sizer. 


\section{References}

2 Armstrong, J. L. and Mackenzie, D. H. (2002). Sediment yields and turbidity records 3 from small upland subcatchments in the Warragamba Dam Catchment, southern New

$4 \quad$ South Wales. Australian Journal of Soil Research, 40(4):557-579.

5 Auzet, A.-V., Boiffin, J., Papy, F., Ludwig, B., and Maucorps, J. (1993). Rill erosion as a 6 function of the characteristics of cultivated catchments in the North of France. Catena, $7 \quad 20: 41-62$.

8 Baudry, J., Bunce, R. G. H., and Burel, F. (2000). Hedgerows: An international perspec9 tive on their origin, function and management. Journal of Environmental Management, 60(1):7-22.

Beuselinck, L., Govers, G., Steegen, A., and Quine, T. A. (1999b). Sediment transport by overland flow over an area of net deposition. Hydrological Processes, 13(17):27692782.

Bos, M. G., Replogle, J. A., and Clemmens, A. J. (1991). Flow measuring flumes for open channel systems. American Society of Agricultural Engineers, St Joseph, Michigan, USA.

Canterford, R. P., Pescod, N. R., J, P. H., and Turner, L. H. (1987). Design intensityfrequency-duration rainfall, chapter 2, pages 13-40. The Institution of Engineers, Australia, $3^{\text {rd }}$ edition. 
1 Cheng, N.-S. (1997). Simplified settling velocity formula for sediment particle. Journal of Hydraulic Engineering, February:149-152.

Chepil, W. S. (1950). Methods of estimating apparent density of discrete soil grains and aggregates. Soil Science, 70:351-362.

5 Cooper, J. R., Gilliam, J. W., Daniels, R. B., and Robarge, W. P. (1987). Riparian areas as filters for agricultural sediment. Soil Science Society of America Journal, 51(2):416420.

8 Dabney, S. M., Meyer, L. D., Harmon, W. C., Alonso, C. V., and Foster, G. R. (1995). De$9 \quad$ positional patterns of sediment trapped by grass hedges. Transactions of the American Society of Agricultural Engineers, 38(6):1719-1729.

Daniels, R. B. and Gilliam, J. W. (1996). Sediment and chemical load reduction by grass and riparian filters. Soil Science Society of America Journal, 60(1):246-251.

Darboux, F., Davy, P., Gascuel-Odoux, C., and Huang, C. (2001). Evolution of soil surface rouhness and flowpath connectivity in overland flow experiments. Catena, 46:125-139.

Deletic, A. (2001). Modelling of water and sediment transport over grassed areas. Journal of Hydrology, 248:168-182.

Deletic, A. (2005). Sediment transport in urban runoff over grassed areas. Journal of Hydrology, 301:108-122.

Deletic, A. (2006). Performance of grass filters used for stormwater treatment - a field and modelling study. Journal of Hydrology, 317:261-275.

DeNovio, N. M., Saiers, J. E., and Ryan, J. N. (2004). Colloid movement in unsaturated porous media: recent advances and future directions. Vadose Zone Journal, 3:338-351.

Dillaha, T. A., Reneau, R. B., Mostaghimi, S., and Lee, D. (1989). Vegetative filter strips for agricultural nonpoint source pollution control. Transactions of the American Society of Agricultural Engineers, 32(2):513-519. 
1 Dillaha, T. A., Sherrard, j. H., Lee, D., S, M., and Shanholtz, V. O. (1988). Evaluation 2 of vegetative filter strips as a best management practice for feed lots. Journal of Water Pollution Control Federation, 60:1231-1238.

4 Dosskey, M. J. (2001). Toward quantifying water pollution abatement in response to $5 \quad$ installing buffers on crop land. Environmental Management, 28(5):577-598.

6 Dosskey, M. J. (2002). Setting priorities for research on pollution reduction functions of $7 \quad$ agricultural buffers. Environmental Management, 30(5):641-650.

8 Driessen, P., Deckers, J., Spaargaren, O., and Nachtergaele, F., editors (2001). Lecture $9 \quad$ notes on the major soils of the world, number 94 in Soil Resources Reports, Roma. Food and Agriculture Organization of the United Nations.

11 Droppelmann, K. and Berliner, P. (2003). Runoff agroforestry - a technique to secure the livelihood of pastoralists in the middle east. Journal of Arid Environments, 54(3):571577.

Ellis, T. W., Leguédois, S., Hairsine, P. B., and Tongway, D. J. (2006). Capture of overland flow by a tree belt on a pastured hillslope in south-eastern Australia. Australian Journal of Soil Research, 44:117-125.

Ghadiri, H., Rose, C. W., and Hogarth, W. L. (2001). The influence of grass and porous barrier strips on runoff hydrology and sediment transport. Transactions of the American Society of Agricultural Engineers, 44:259-268.

Hairsine, P. B. (1996). Comparing grass filter strips and near-natural riparian forests for buffering intense hillslope sediment sources. In Rutherfurd, I. and Walker, M., editors, Proceedings of First National Conference on Stream Management in Australia, pages 203-206. Cooperative Research Centre for Catchment Hydrology, Merrijig, Australia.

Hairsine, P. B. and McTainsh, G. (1986). The Griffith tube: A simple settling tube for 
the measurement of settling velocity of aggregates. Technical Report 3/86, School of Australian Environmental Studies, Griffith University, Australia.

Hardy, I. A. J., Garter, A. D., Leeds-Harrison, P. B., Sanders, R. M., and I, F. (1999). The origin of sediments in field drainage water. In Tracers in Geomorphology. John Wiley and Sons.

Hayes, J. C., Barfield, B. L., and Barnhisel, R. I. (1984). Performance of grass filters under laboratory and field conditions. Transactions of the American Society of Agricultural Engineers, 27:1321-1331.

Helmers, M. J., Eisenhauer, D. E., Dosskey, M. G., Franti, T. G., Brothers, J. M., and McCullough, M. C. (2005). Flow pathways and sediment trapping in a field-scale vegetative filter. Transactions of the American Society of Agricultural Engineers, 48(3):955968.

Jin, C.-X., Dabney, S. M., and Römkens, M. J. M. (2002). Trapped mulch increases sediment removal by vegetative filter strips: a flume study. Transations of the American Society of Agricultural Engineers, 45(4):929-939.

Jin, C.-X. and Römkens, M. J. M. (2001). Experimental studies of factors in determining sediment trapping in vegetative filter strips. Transations of the American Society of Agricultural Engineers, 44(2):277-288.

Kang, B. T., L, R., and Atta-Krah, A. N. (1990). Alley farming. Advances in Agronomy, $43: 315-359$.

Kanti Sen, T. and Khilar, K. C. (2006). Review on subsurface colloids and colloidassociated contaminant transport in saturated porous media. Advances in Colloid and Interface Science, 119(2-3):71-96.

Lacas, J.-G., Voltz, M., Gouy, V., Carluer, N., and Gril, J.-J. (2005). Using grassed 
7 Lee, K.-H., Isenhart, T. M., Schultz, R. C., and Mickelson, S. K. (2000). Multispecies

strips to limit pesticide transfer to surface water: a review. Agronomical Sustainable Development, 25(2):253-266.

Le Bissonnais, Y., Lecomte, V., and Cerdan, O. (2004). Grass strip effects on runoff and soil loss. Agronomie, 24:129-136.

Lee, D., Dillaha, T. A., and Sherrard, J. H. (1989). Modeling phosphorus transport in grass buffer strips. Journal of Environmental Engineering, 115(2):409-427.

riparian buffers trap sediment and nutrients during rainfall simulations. Journal of Environmental Quality, 29:1200-1205.

Léonard, J., Perrier, E., and Rajot, J.-L. (2004). Biological macropores effect on runoff and infiltration: a combined experimental and modelling approach. Agriculture, Ecosystems and Environment, 104:277-285.

Lickfeldt, D. W. and Branham, B. E. (1995). Sorption of nonionic compounds by kentucky bluegrass leaves and thatch. Journal of Environmental Quality, 24:980-985.

Loch, R. J. (2001). Settling velocity - a new approach to assessing soil and sediment properties. Computers and Electronics in Agriculture, 31:305-316.

Loch, R. J., Espigares, T., Costantini, A., Garthe, R., and Bubb, K. (1999). Vegetative filter strips to control sediment movement in forest plantations: validation of a simple model using field data. Australian Journal of Soil Research, 37(5):929-946.

Mackenzie, D. H. and Hairsine, P. B. (1996). The hydraulics of shallow overland flow: a comparison between a grass filter strip and a near-natural riparian forest. In Rutherfurd, I. and Walker, M., editors, Proceedings of First National Conference on Stream Management in Australia, pages 207-211. Cooperative Research Centre for Catchment Hydrology, Merrijig, Australia. 
1 Meyer, L. D., Dabney, S. M., and Harmon, W. C. (1995). Sediment-trapping effectiveness

2 of stiff-grass hedges. Transactions of the American Society of Agricultural Engineers, 38(3):809-815.

4 Muñoz-Carpena, R. and Parsons, J. E. (2004). A design procedure for vegetative filter

5 strip using VFSMOD-W. Transations of the American Society of Agricultural Engi-

$6 \quad$ neers, 47(6):1933-1941.

7 Muñoz-Carpena, R., Parsons, J. E., and Gilliam, J. W. (1999). Modeling hydrology and sediment transport in vegetative filter strips. Journal of Hydrology, 214(1/4):111-129.

9 Øygarden, L., Kvaerner, J., and Jenssen, P. D. (1997). Soil erosion via prefenrential flow to drainage systems in clay soils. Geoderma, 76(1-2):65-86.

11 Park, E.-J. and Smucker, A. J. M. (2005). Erosive strengths of concentric regions within 
1 Stirzaker, R., Vertessy, R., and Sarre, A., editors (2002). Trees, water and salt. An Aus2 tralian guide to using trees for healthy catchments and productive farms, Barton, Aus3 tralia. Joint Venture Agroforestry Progran, CSIRO, Cooperative Research Centre for $4 \quad$ Catchment Hydrology, Rural Industries Research and Development Corporation, Rural $5 \quad$ Industries Research and Development Corporation.

6 Takken, I., Beuselinck, L., Nachtergaele, J., Govers, G., Poesen, J., and Degraer, G. 7 (1999). Spatial evaluation of a physically-based distributed erosion model LISEM. $8 \quad$ Catena, 37:431-447.

9 Tongway, D. J. and Hindley, N. L. (2004). Landscape function analysis manual: Procedures for monitoring and assessing landscapes with special reference to minesites and rangelands. CSIRO Sustainable Ecosystems, Canberra, Australia.

van Dijk, P. M., Auzet, A.-V., and Lemmel, M. (2005). Rapid assessment of field erosion and sediment transport pathways in cultivated catchments after heavy rainfall events. Earth Surface Processes and Landforms, 30(2):169-182. sediment by grass strips. Hydrological Processes, 10:1069-1080.

17 Wilson, C. J. (1999). Effects of logging and fire on runoff and erosion on highly erodible granitic soils in Tasmania. Water Resources Research, 35:3531-3546. 


\section{List of Figures}

$2 \quad 1$ Plot layout of the experiment. . . . . . . . . . . . 34

32 Comparison of the ASDs of samples sieved at 1680 and $595 \mu \mathrm{m} . \ldots 35$

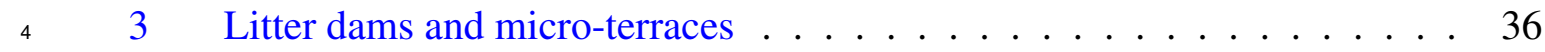

54 Temporal evolution of the MWD of the ASDs . . . . . . . . . . 37

$6 \quad 5$ Average Fragment Size Distributions of the collected sediments. . . . . . 38

76 Settling velocity distributions. . . . . . . . . . . . . 39

87 Fitting of the COF size distribution to the total sediment aggregate size

9 distribution .................... 40

10 8 Computed ASDs of the COF and the MSF from plot P+TB, event \# 2. . . 41

${ }_{11} 9$ MSF budget by size fraction for rainfall event \# $2 \ldots \ldots \ldots$. . . . 42 


\section{Figures}

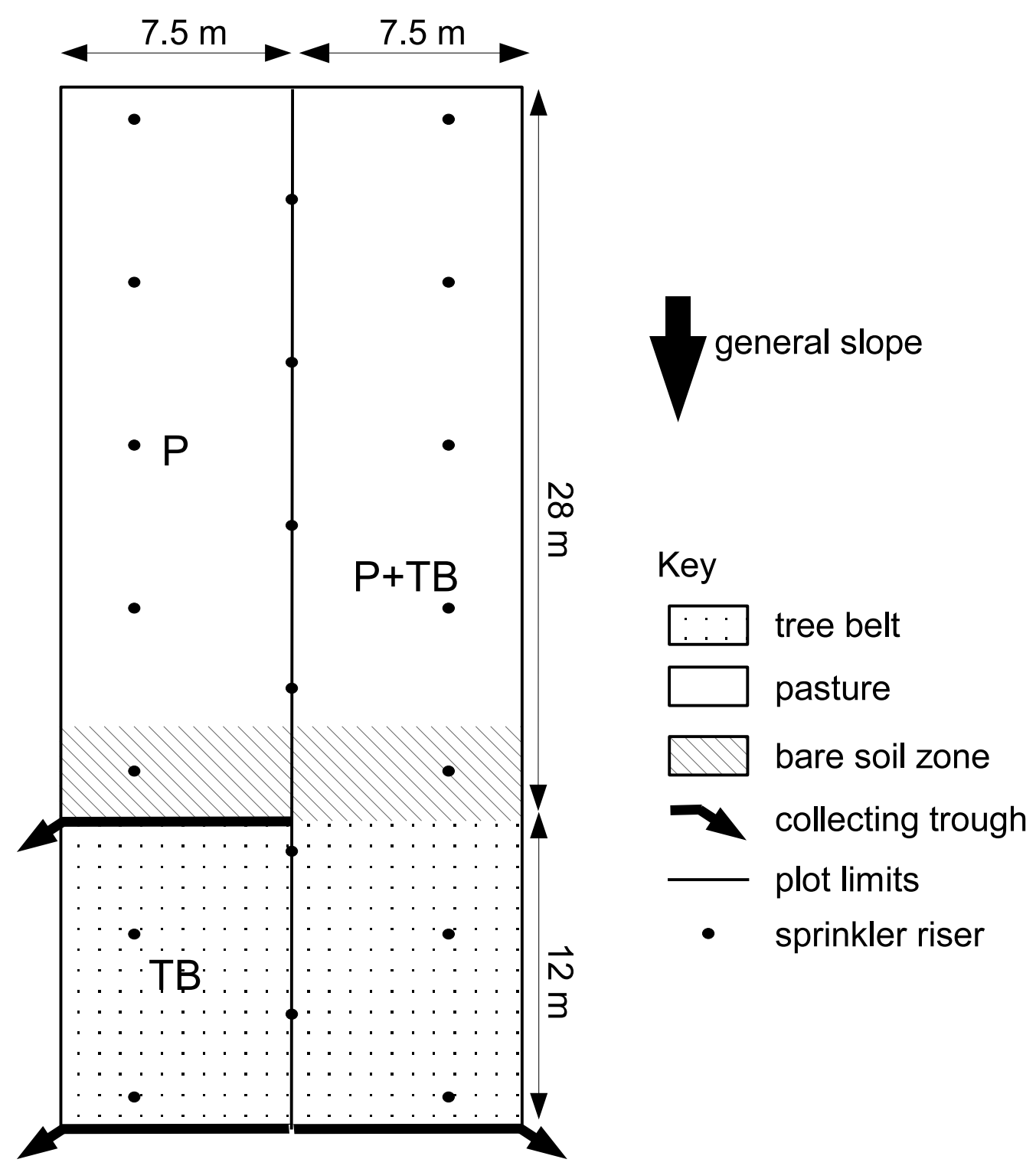

Figure 1: Plot layout (not drawn to scale) of the experiment.

P: pasture plot; TB: tree belt plot; $\mathrm{P}+\mathrm{TB}$ : pasture + tree belt plot 


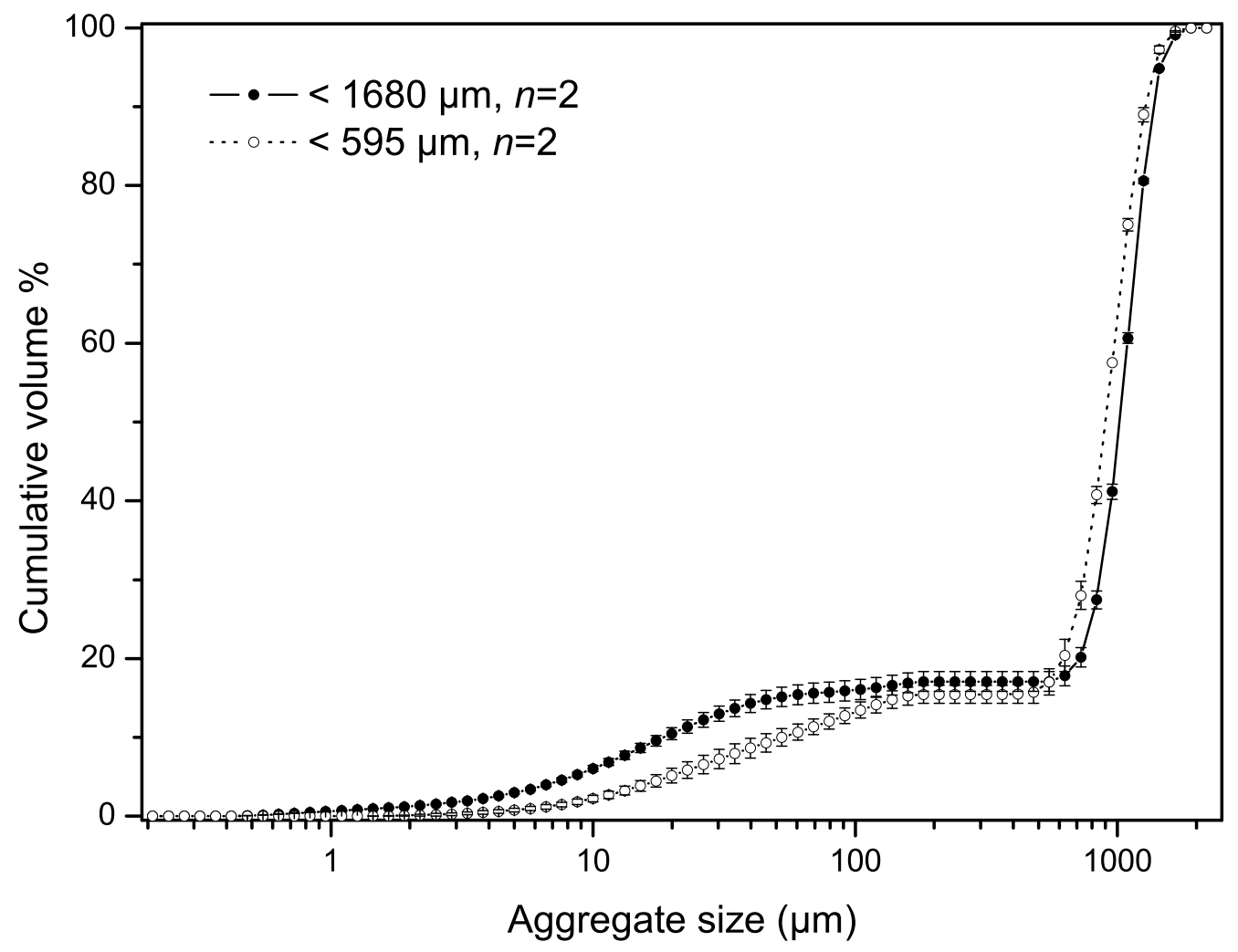

Figure 2: Comparison of the size distribution of samples obtained with sieve size 1680 and $595 \mu \mathrm{m}$ from plot P+TB during event \# 2 .

Error bars represent standard errors. $n$ is the number of samples. 


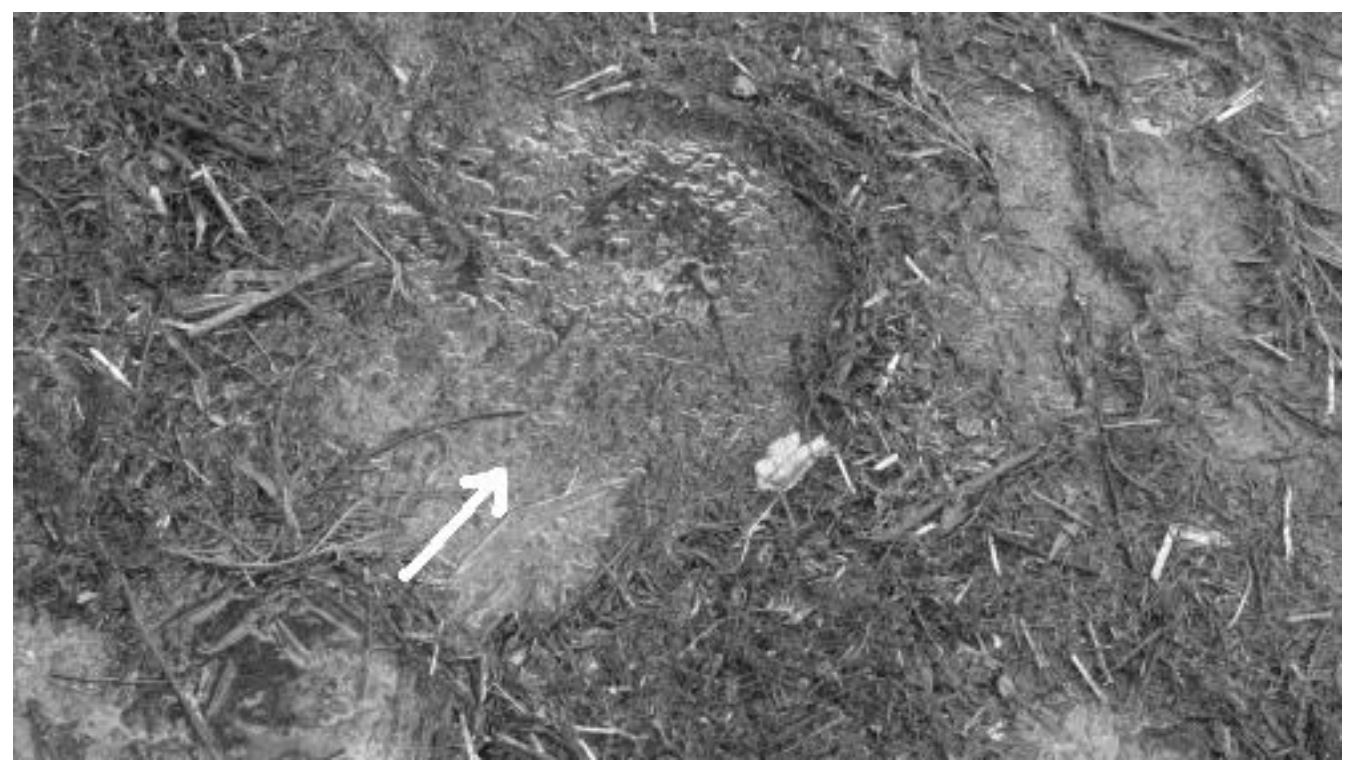

Figure 3: View of the litter dams and the related micro-terraces formed within the tree belt during the rainfall events.

The white arrow shows the flow direction. 


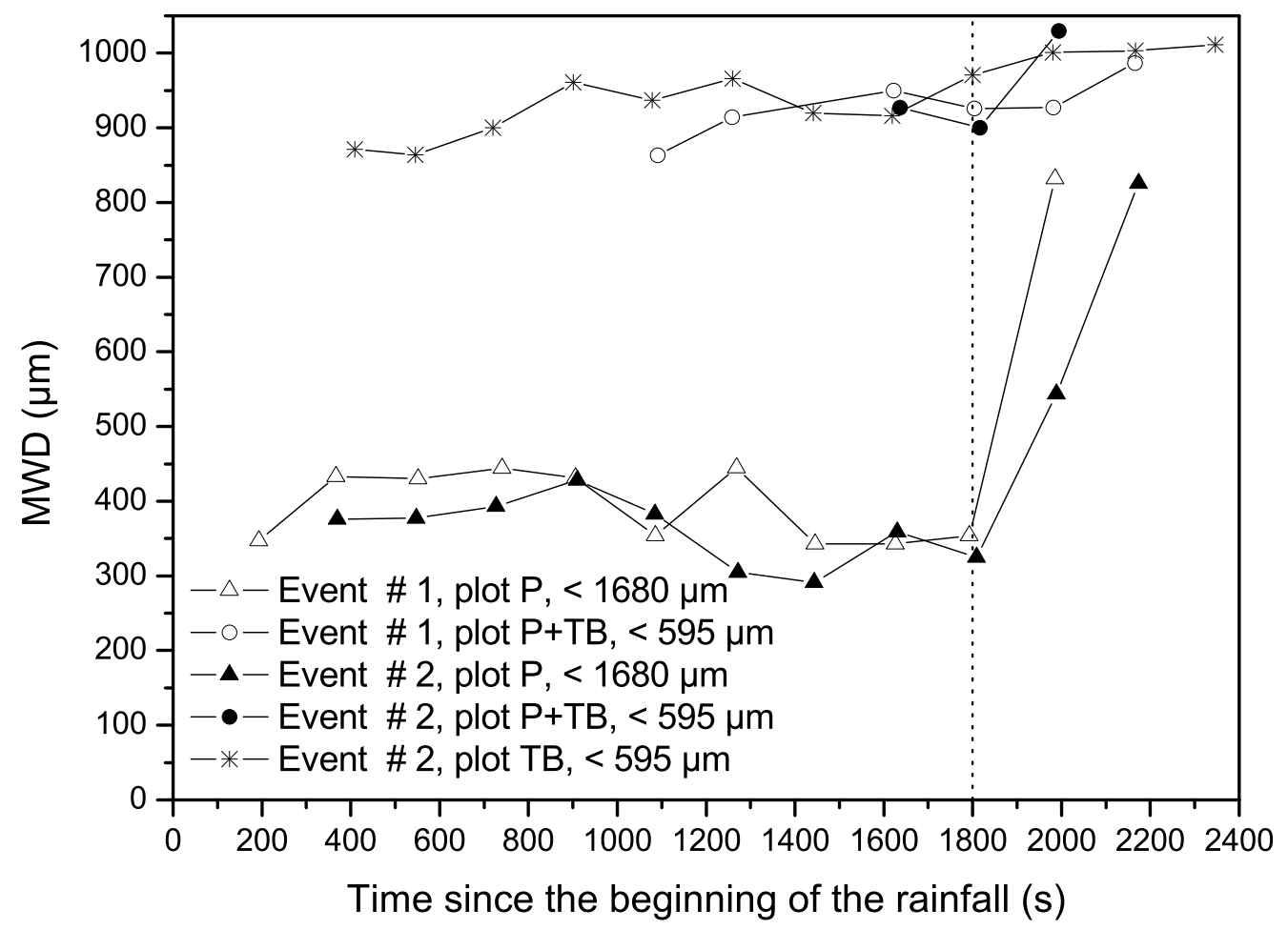

Figure 4: Temporal evolution of the Mean Weight Diameter of the Aggregate Size Distributions.

The vertical dashed line indicates the end of the rainfall simulation. 


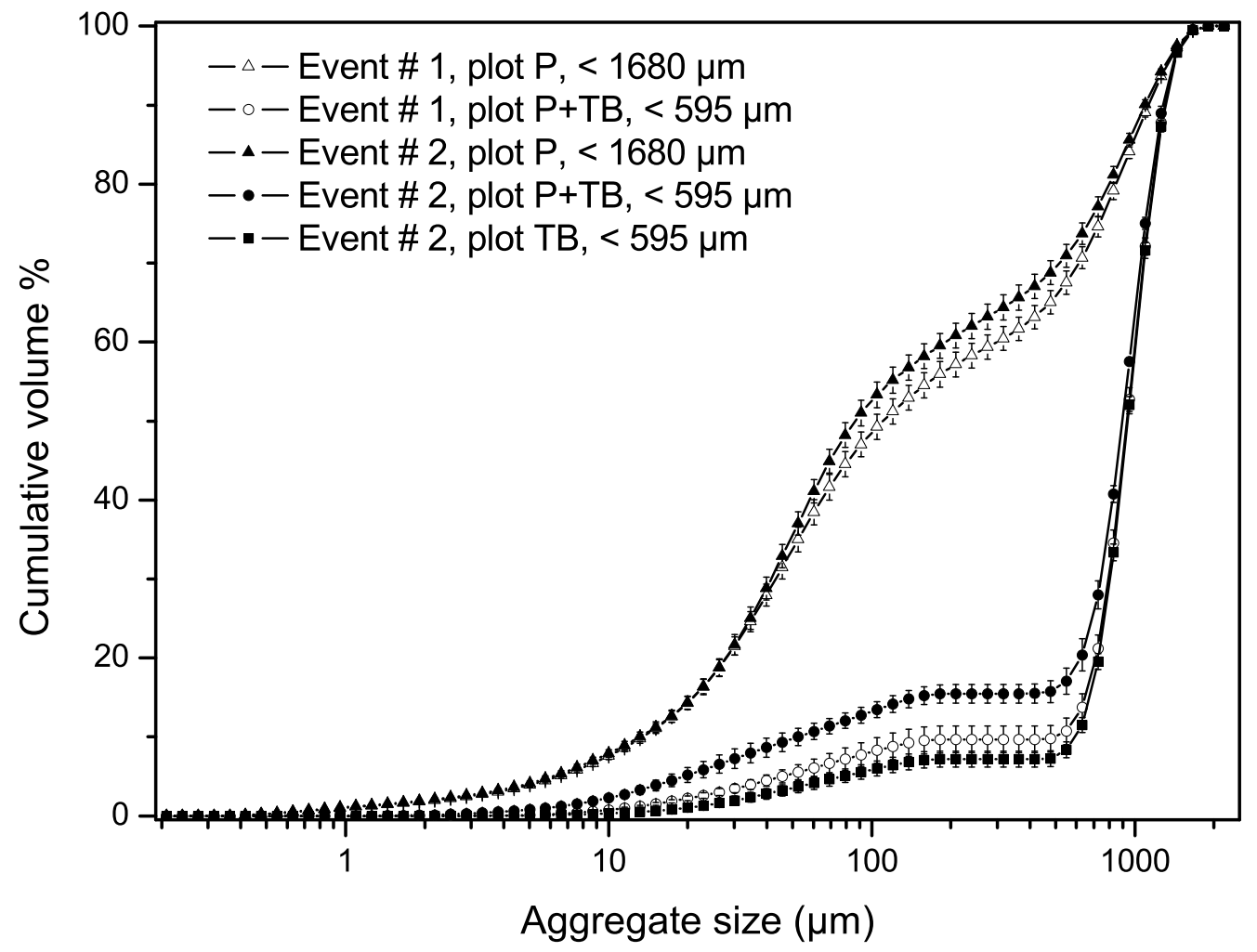

Figure 5: Average Aggregate Size Distributions (ASDs) of the sediments collected at the outlet of plots $\mathrm{P}, \mathrm{P}+\mathrm{TB}$ and TB during the rainfall period of events \# 1 and \# 2 . The error bars represent the standard errors. 


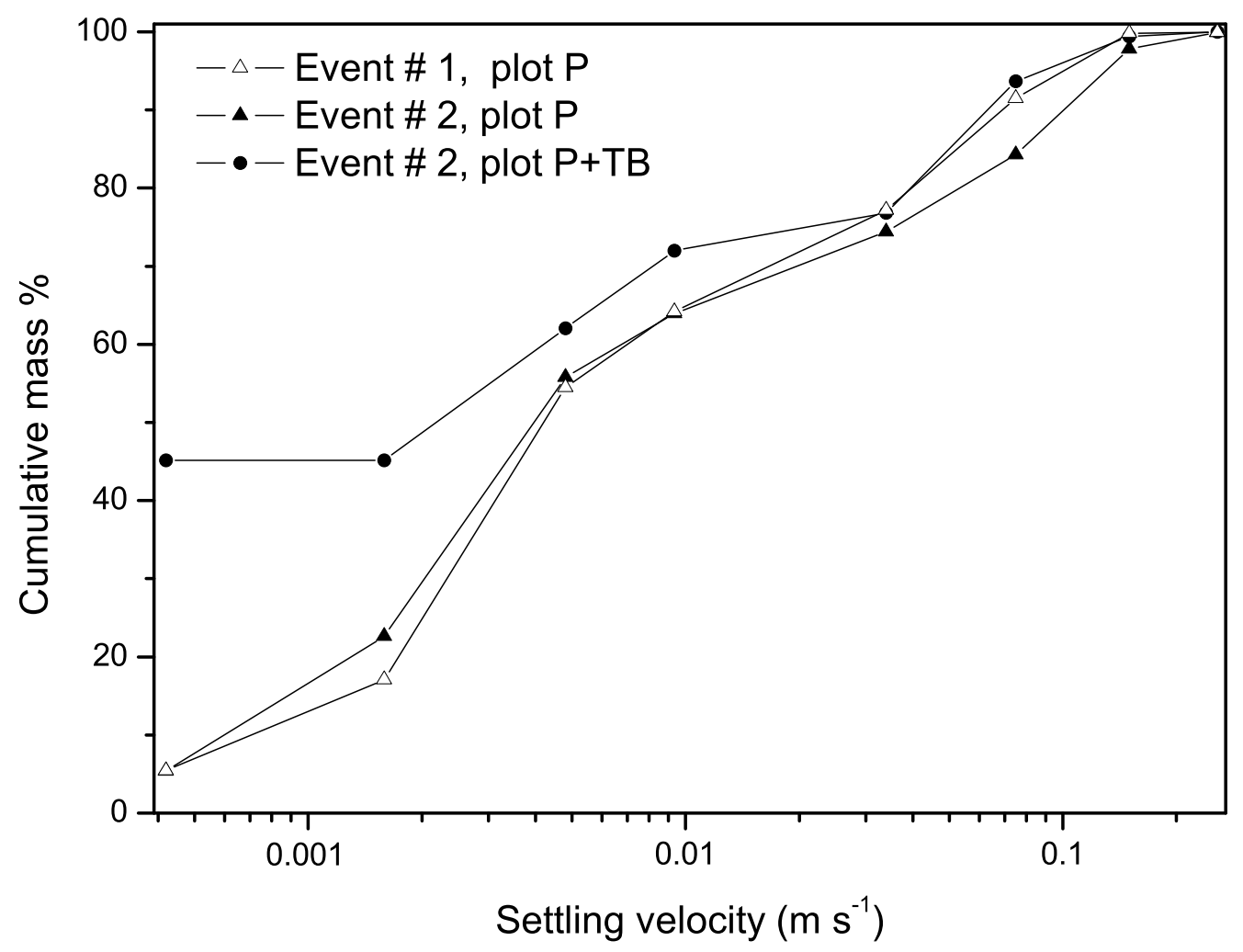

Figure 6: Settling velocity distributions measured for the sediment collected at the outlet of plot $\mathrm{P}$ during rainfall events \# 1 and \# , and plot $\mathrm{P}+\mathrm{TB}$ during rainfall event \# 2 respectively. 


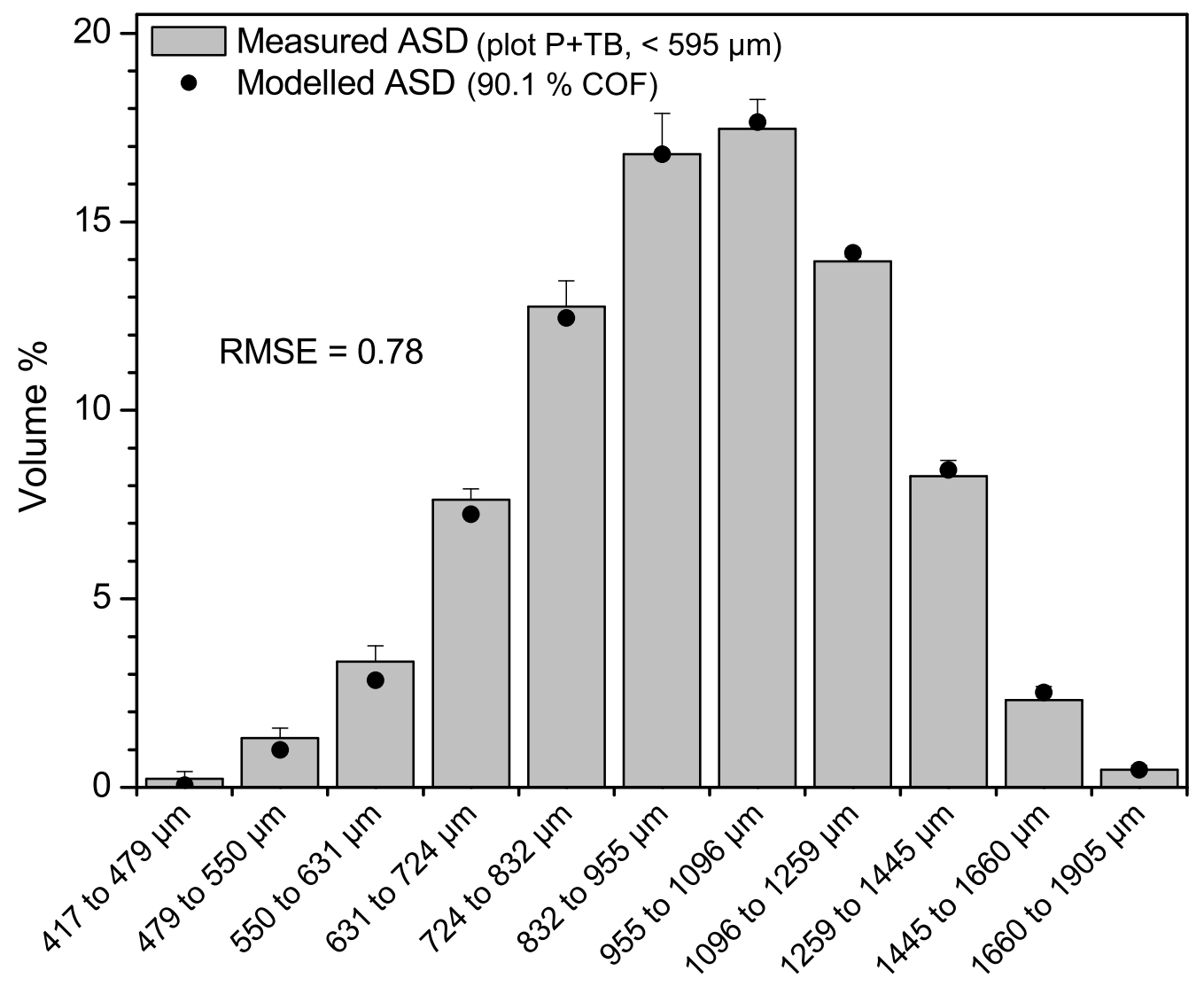

Figure 7: Fitting of the COF aggregate size distribution to the aggregate size distribution measured for plot P+TB for event \# 2.

ASD: Aggregate Size Distribution; RMSE: Root Mean Square Error; COF: Coarse Organic Fragments.

The error bars represent the standard errors on the measured aggregate size distribution. 


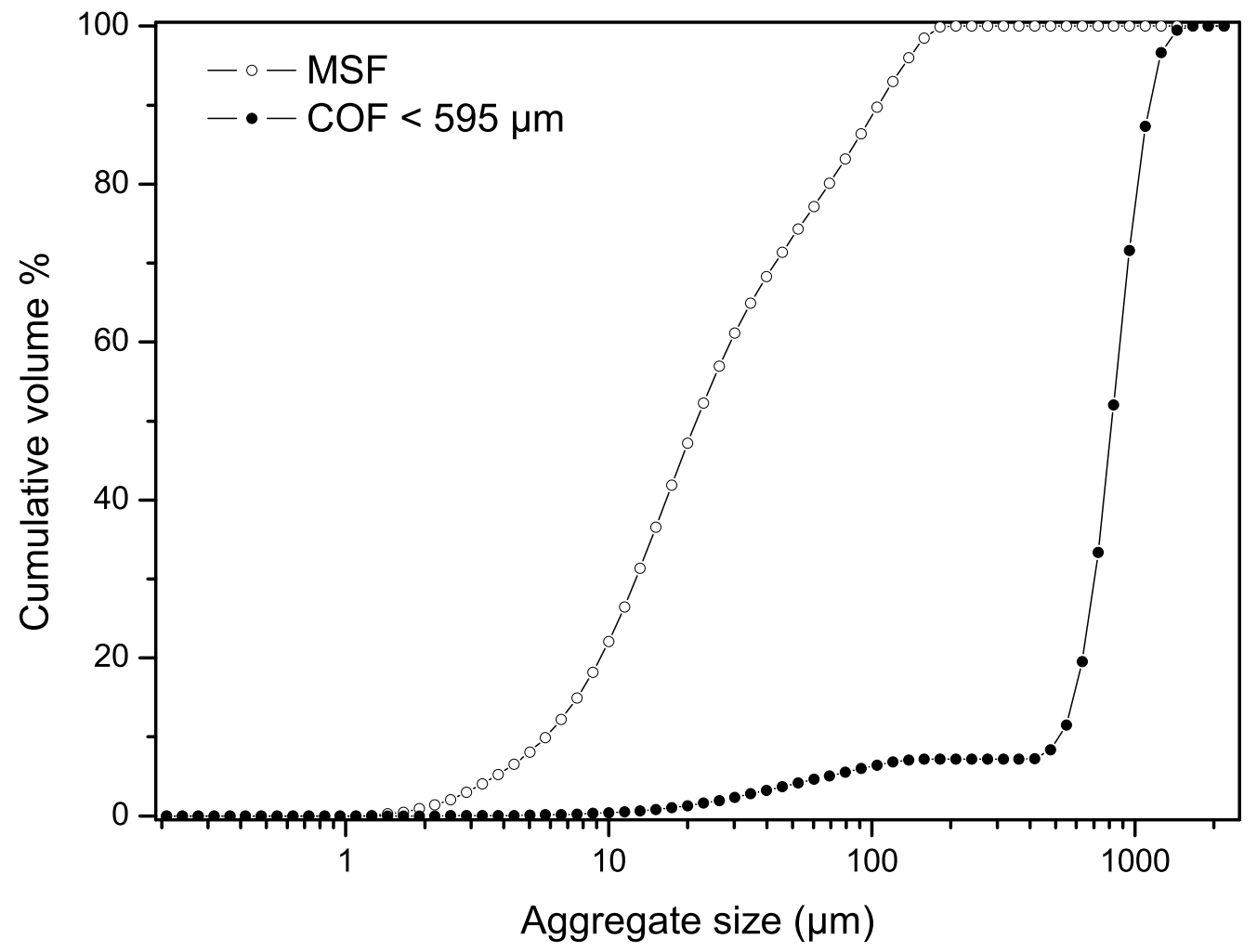

Figure 8: Aggregate size distributions of the COF and the MSF computed for plot $\mathrm{P}+\mathrm{TB}$, event \# 2.

COF: Coarse Organic Fragments; MSF: Mineral Soil Fragments. 


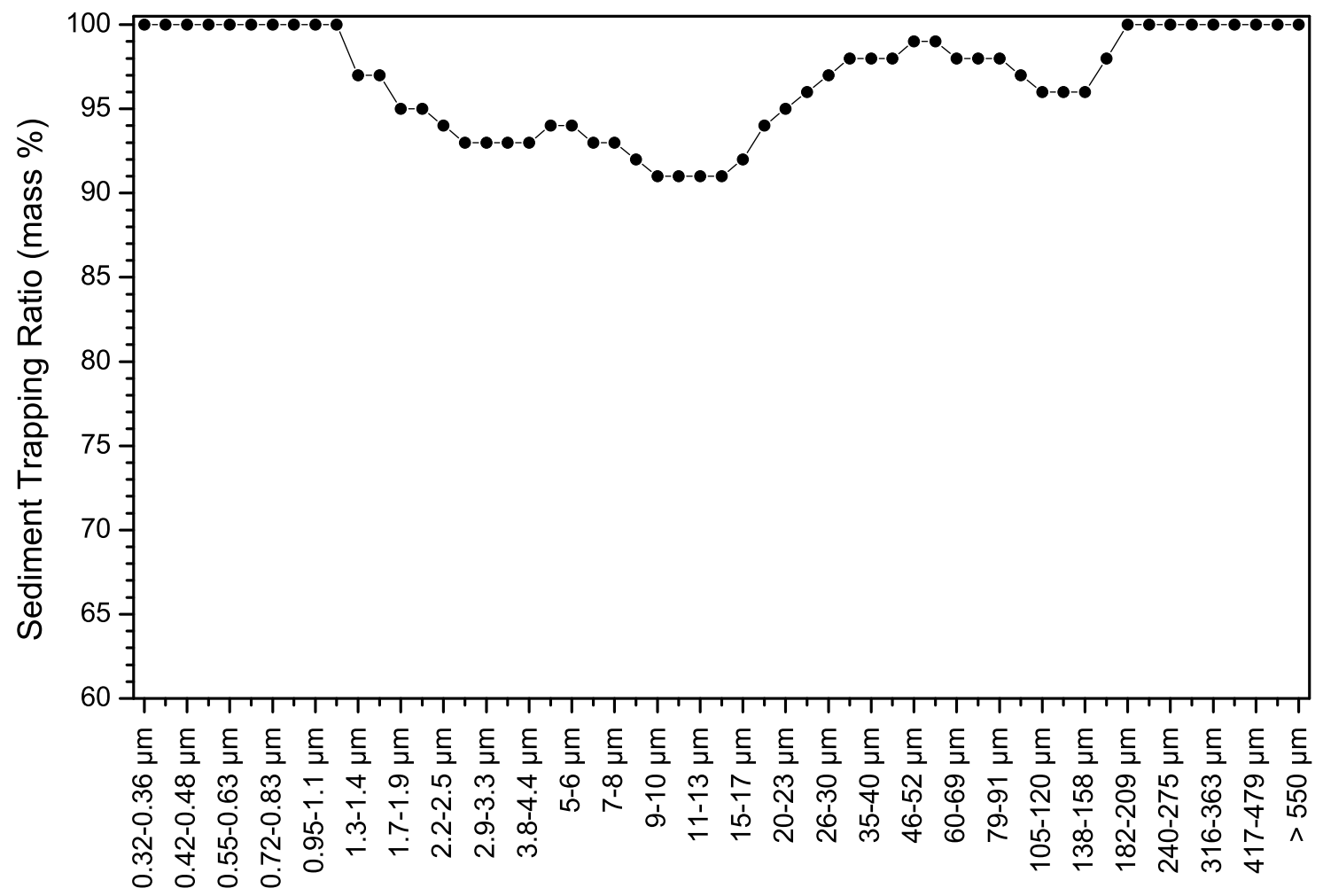

Figure 9: Mineral Soil Fragments budget by size fraction for rainfall event \# 2. This budget was computed for a bulk density, $\rho_{d}(M S F)$, of $2.2 \mathrm{~g} \cdot \mathrm{cm}^{-3}$ measured by Chepil (1950) for silt loam aggregates $<500 \mu \mathrm{m}$. 


\section{List of Tables}

$2 \quad 1$ Characteristics of the simulated rainfall events. . . . . . . . . . 44

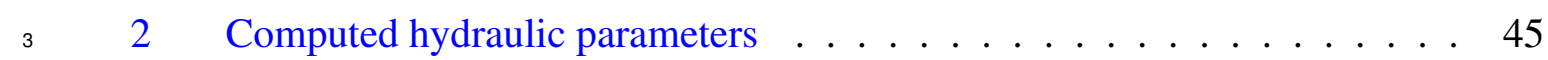

$4 \quad 3$ Dry and wet bulk densities of the oversize COF ........... 46

54 Total sediment exportations and budget . . . . . . . . . . . 47 


\begin{tabular}{lccc}
\hline Rainfall event & Pre-wetting & $\# 1$ & $\# 2$ \\
\hline Duration (min) & 13 & 30 & 30 \\
Rainfall intensity $\left(\mathrm{mm} \cdot \mathrm{h}^{-1} \pm \mathrm{SD}\right)$ & & & \\
$\quad$ Experimental area & $48 \pm 22$ & $49 \pm 23$ & $75 \pm 38$ \\
$\quad$ Pasture plot & $47 \pm 25$ & $50 \pm 25$ & $72 \pm 43$ \\
$\quad$ Pasture + tree belt plot & $52 \pm 23$ & $49 \pm 22$ & $82 \pm 40$ \\
Median drop size $(\mathrm{mm})$ & 1.6 & 1.6 & 2.0 \\
ARI $(\mathrm{y})$ & $\simeq 2$ & $\simeq 10$ & $\simeq 50$ \\
\hline
\end{tabular}

Table 1: Characteristics of the simulated rainfall events.

SD: Standard Deviation. Rainfall intensity was measured with a network of 24 raingauges on the pasture part of the experimental plot.

ARI: Average Recurrence Interval. Data for the determination of the ARI were prepared by the Hydrometeorological Advisory Service, Melbourne, Commonwealth of Australia, Bureau of Meteorology as indicated in Canterford et al. (1987). 


\begin{tabular}{ccccccc}
\hline \multirow{2}{*}{ Rainfall event } & \multicolumn{2}{c}{$\begin{array}{c}\text { Flow depth } \\
\mathrm{mm} \pm \text { AME }\end{array}$} & \multicolumn{2}{c}{$\begin{array}{c}\text { Average flow velocity } \\
\mathrm{m} \cdot \mathrm{s}^{-1} \pm \text { AME }\end{array}$} & \multicolumn{2}{c}{$\begin{array}{c}\text { Hydraulic roughness } \\
n\end{array}$} \\
\cline { 2 - 7 } & Pasture & Tree belt & Pasture & Tree belt & Pasture & Tree belt \\
\hline$\# 1$ & $2.3 \pm 0.3$ & $7.2 \pm 0.5$ & $0.06 \pm 0.01$ & $0.02 \pm 0.00$ & $0.01-0.05$ & $0.12-0.28$ \\
$\# 2$ & $7.5 \pm 2.4$ & $11.3 \pm 2.7$ & $0.04 \pm 0.01$ & $0.03 \pm 0.01$ & $0.03-0.17$ & $0.08-0.24$ \\
\hline
\end{tabular}

Table 2: Hydraulic parameters computed by Ellis et al. (2006) from the discharge data. AME: Absolute Measurement Errors. $n$ is Manning's hydraulic roughness. 


\begin{tabular}{llcc}
\hline Fraction & Description & $\begin{array}{c}\rho_{d} \\
\mathrm{~g} \cdot \mathrm{cm}^{-3}\end{array}$ & $\begin{array}{c}\rho_{w} \\
\mathrm{~g} \cdot \mathrm{cm}^{-3}\end{array}$ \\
\hline Callistemon spp. & Whole leaves and leaf fragments & 0.27 & 0.59 \\
Round & Mainly small sticks, some small spherical fruits, some grass & 0.59 & 1.15 \\
Flat & Mainly Acacia ssp. leaf fragments, some moss & 1.03 & 1.84 \\
\hline Total COF & & 0.50 & 0.95 \\
\hline
\end{tabular}

Table 3: Dry and wet bulk densities of the oversize Coarse Organic Fragments. $\rho_{d}$ : dry bulk density; $\rho_{w}$ : wet bulk density; COF: Coarse Organic Fragments. 


\begin{tabular}{ccccc}
\hline Rainfall event & \multicolumn{3}{c}{ Total mass of sediment exported (kg) } & STR \\
& Pasture & Pasture + tree belt & Tree belt & $\%$ \\
\hline$\# 1$ & 19.8 & 0.9 & 0.01 & 95 \\
$\# 2$ & 41.3 & 2.7 & 0.35 & 94 \\
\hline Total & 61.1 & 3.6 & 0.36 & \\
\hline
\end{tabular}

Table 4: Total sediment exportations and budget.

STR: Sediment Trapping Ratio in mass percentage. 